\title{
Adult cold tolerance and potential North American distribution of Myllocerus undecimpustulatus undatus (Coleoptera: Curculionidae)
}

\author{
Anita S. Neal · Rodrigo Diaz $\cdot$ Jawwad A. Qureshi $\cdot$ Ronald D. Cave $\mathbb{C}$
}

Received: 22 June 2020/Accepted: 7 July 2021 / Published online: 31 July 2021

(C) The Author(s) 2021

\begin{abstract}
Cold tolerance and potential distribution of Myllocerus undecimpustulatus undatus Marshall, a polyphagous pest in the United States, were investigated. Adult survivorship after 2 days at $0{ }^{\circ} \mathrm{C}$ and $-5{ }^{\circ} \mathrm{C}$ averaged $60 \%$ and $18 \%$, respectively. Four days of exposure resulted in survivorship of $11 \%$ at $0{ }^{\circ} \mathrm{C}$ and $4 \%$ at $-5{ }^{\circ} \mathrm{C}$, respectively. Summercollected weevils at $-5{ }^{\circ} \mathrm{C}$ through repeated cold exposure of $2 \mathrm{~h}$ survived 3 times longer than those subjected to sustained cold period of $10 \mathrm{~h}$. Leaf consumption did not differ among summer-collected weevils at constant $20^{\circ} \mathrm{C}$ and repeated cold exposure treatments; weevils under sustained cold exposure consumed less than weevils in repeated cold exposure treatments. Leaf area consumed after cold exposure
\end{abstract}

A. S. Neal · R. D. Cave $(\bowtie)$

Entomology and Nematology Department, Institute of Food and Agricultural Sciences, Indian River Research and Education Center, University of Florida, 2199 South Rock Road, Fort Pierce, FL 34945, USA

e-mail: rdcave@ufl.edu

R. Diaz

Louisiana State University Agricultural Center, 402 Life

Sciences Building, Baton Rouge, LA, USA

J. A. Qureshi

Entomology and Nematology Department, Institute of Food and Agricultural Sciences, Southwest Florida Research and Education Center, University of Florida, 2685 State Road 29 North, Immokalee,

FL 34142, USA was 2-4 times greater in winter-collected weevils compared to summer-collected weevils. Leaf consumption by winter-collected weevils decreased as the number of repeated cold exposure periods increased. Locality data from collections in Florida during 2000-2012 were used to produce a correlative model complemented by a mechanistic model from the cold tolerance data to project the potential distribution of M. undecimpustulatus undatus in North America. The models support the hypothesis that $M$. undecimpustulatus undatus could spread to areas of the southeastern and western United States. The predicted northern distribution followed an isothermal line about $33^{\circ}$ North. The niche model defined an area along the western Gulf Coast as unsuitable for the weevil, possibly because the area receives greater annual rainfall than other areas of the southeastern United States and has aquic or udic soil unlike the welldrained sandy soil of peninsular Florida.

Keywords GIS mapping · Invasive weevil · Isothermal line $\cdot$ Repeated cold exposure $\cdot$ Sustained cold exposure

\section{Introduction}

Upon arrival to a new region, tropical insects face biotic and abiotic factors that might limit their 
establishment and subsequent colonization (Andrewartha and Birch 1954). Winter temperature is probably the most important abiotic factor limiting the establishment of tropical insects in subtropical and temperate regions (Singh et al. 2009). However, insects exposed to cooler temperatures may evolve morphological, physiological, and behavioral adaptations (Lalouette et al. 2007), which could potentially enable them to colonize new regions (Bale 2002). Three examples of tropical pest insects that overcame mild winter temperatures to establish in semitropical Florida are the lobate lac scale, Paratachardina pseudolobata Kondo \& Guillan (Chong et al. 2008), the West Indian drywood termite, Cryptotermes brevis Walker (Scheffrahn and Su 1999), and the papaya mealybug, Paracoccus marginatus Williams and Granara de Willink (Amarasekare et al. 2008). Moreover, a tropical insect's capacity to develop within a broad range of temperatures is a key adaptation to endure changing climatic conditions, which is important in predicting insect outbreaks and developing effective management strategies (Amarasekare et al. 2008; Bale 2002; Manrique et al. 2012).

One of the tools to evaluate the potential spread of an insect is a species distribution model. The model employs parameters from climatic variables, such as rainfall and temperature, where a species currently exists to predict the possibility of the species survival in other areas that share similar climatic conditions (Guisan and Zimmermann 2000; Araújo and Peterson 2012). Species distribution models apply geographic information systems (GIS), along with computer software packages and climate databases, to predict a species' spread (Elith and Leathwick 2009; Franklin 2010; Stratman et al. 2014). These models have been used to predict the geographical distribution of adventive species, biological control agents, and crop pests into other regions (e.g., Lapointe et al. 2007; Tognelli et al. 2009; Stratman et al. 2014). However, there are concerns with the use of correlative models to predict species distribution. These concerns include the basis of selecting the predictor variables that limit a species' distribution, the specific factors of the species' geographic or environmental range that are estimated, the methods chosen to transform probabilities of suitability onto maps, incomplete data, and the models are hypotheses that should be supported with additional data (Araújo and Peterson 2012; Jarnevich et al. 2015).
Mechanistic species distribution models, on the other hand, focus on the variables of biological or physiological processes that constrain where a species might survive and reproduce. Hypotheses from these models can be tested by field sampling and observation. Cold tolerance is one such biological process that limits a species' distribution and has been extensively studied in insects to develop species distribution models (e.g., Diaz et al. 2008; Manrique et al. 2008, 2012; Stratman et al. 2014). Kearney et al. (2010) argue that mechanistic and correlative models may congruently provide accurate predictions of expanded distribution due to climate change or dispersal of invasive species.

Cold tolerance studies usually focus on the effects of a single cold exposure on the developmental and physiological processes of insects under laboratory conditions (Lalouette et al. 2007; Diaz et al. 2008; Manrique et al. 2008, 2012). However, insects experience variable temperature exposure in natural environments, even several times within a "winter" season (Marshall and Sinclair 2012). The fluctuations in temperature between night and day may be up to $20{ }^{\circ} \mathrm{C}$, exposing them to cyclical cold stress (Marshall and Sinclair 2010). Because fluctuating thermal regimes are common in natural habitats, insects that are active year-round may take advantage of periods of favorable temperatures to feed or recover from damages caused by low temperatures (Lalouette et al. 2007). Marshall and Sinclair (2010, 2012) looked at repeated cold exposures with Drosophila melanogaster Meigen (Diptera: Drosophilidae) crossing the chill-coma threshold (at or below $10{ }^{\circ} \mathrm{C}$ ) at which all muscular movement ceases. They found that repeated cold exposures improved cold tolerance when compared to insects experiencing a single, prolonged cold exposure.

Myllocerus undecimpustulatus undatus Marshall (Coleoptera: Curculionidae) is a polyphagous broadnosed weevil native to Sri Lanka (Ramamurthy and Ghai 1988), which is within the equatorial climatic zone (Zone I) that experiences mean seasonal temperature differences less than the mean daily temperature variations (Walter et al. 1975). The climate of this island off the southern coast of India is tropical, with average annual temperatures ranging 26.5-28.5 ${ }^{\circ} \mathrm{C}$ and mean annual rainfall from $900 \mathrm{~mm}$ in the northwestern and southeastern 
lowlands to over $5000 \mathrm{~mm}$ on the southwestern highland slopes (Department of Meteorology Sri Lanka 2021).

Myllocerus undecimpustulatus undatus was first detected in Florida in 2000 (O'Brien et al. 2006), and by 2013 the Division of Plant Industry (DPI) of the Florida Department of Agriculture and Consumer Services (FDACS) reported its presence in 27 Florida counties (Fig. 1). Walter et al. (1975) characterize the coastal climate of Florida as the humid subtropical zone (Zone II), with average annual temperature of $21.5{ }^{\circ} \mathrm{C}$ (Current Results Publishing Ltd 2021). Therefore, the weevil's establishment and spread throughout Florida is not unexpected.

The adults of $M$. undecimpustulatus undatus are folivores of over 150 plant species (Neal 2013), including ornamental plants, fruit trees, and vegetables. The larvae injure roots (O'Brien et al. 2006), but the full range of larval hosts is unknown. Larvae have been reared in very small numbers on the roots of Ipomoea batatas L. (sweet potato), Capsicum spp. L. (pepper), Solanum melongena L. (eggplant), and Daucus carota sativus L. (carrot) (O'Brien et al. 2006; Neal 2013). Emergence traps placed along the dripline have captured adults emerging from under mango, lychee, longan, and Pouteria sapota (Jacq.) H.E. Moore \& Stearn (mamey sapote) trees (Epsky et al. 2009) in southern Florida. Soil moisture requirements for larval survival are unknown.

There is no information on the fecundity of $M$. undecimpustulatus undatus, but other Myllocerus species may lay up to 360 eggs over a 24-day period,

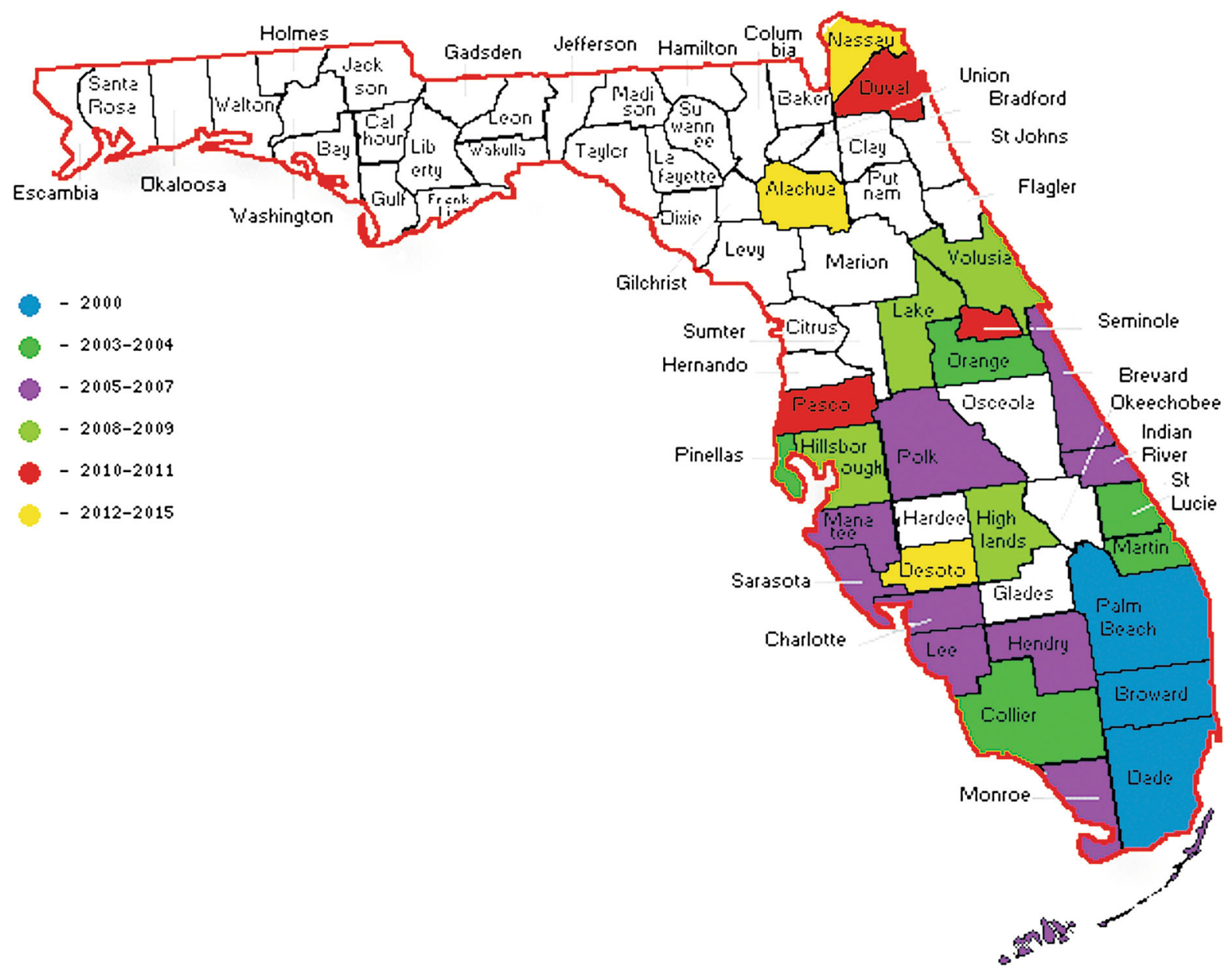

Fig. 1 Distribution of Myllocerus undecimpustulatus undatus by county in Florida based on collection information from 2000 through 2015 from the Florida Department of Agriculture and Consumer Services, Division of Plant Industry 
and larvae emerge in 3-5 days (Atwal 1976). Myllocerus undecimpustulatus undatus eggs are less than $0.5 \mathrm{~mm}$, ovoid, and usually laid in clusters of 8-35 directly on organic material at the soil surface. Larvae feed on plant roots for approximately 1-2 months and pupate in the soil for approximately one week inside an earthen cell. The weevil's life cycle under unspecified laboratory conditions is approximately two months (Mannion et al. 2006). Myllocerus undecimpustulatus undatus undergoes no apparent dormancy in Sri Lanka, India, or the United States.

Arévalo and Stansly (2009) found high infestations of the weevil in citrus groves, and observations report damage to avocado, peaches, and lychee (R. Adair and M. Luciano, personal communication, April 2015, 2016, respectively). Management depends largely on pesticides, which provide limited control due to the adult's ability to fly, hide, or feign death and drop to the ground (Neal 2013). Chemical control of the eggs, larvae, and pupae is challenging due to their location in the soil (Neal 2013).

Year-round activity and reproduction, polyphagy, and immature stages that are hidden in substrate allow M. undecimpustulatus undatus to colonize new areas and become broadly distributed. But despite its pest status, there is limited information regarding the influence of temperature on survival and the potential geographic range of $M$. undecimpustulatus undatus. The objectives of this study were to (1) determine survivorship of adult $M$. undecimpustulatus undatus after cold temperature exposures, (2) measure survival and food consumption by adults after repeated cold exposure, and (3) use cold tolerance data and climate niche modeling to determine the potential distribution of M. undecimpustulatus undatus in North America. Objectives 1 and 2 provided data for mechanistic modeling, whereas objective 3 collected data for a correlative model. With these tandem models, we hypothesize that $M$. undecimpustulatus undatus may be able to expand its distribution outside of tropical and subtropical regions to southern and western temperate regions of North America.

\section{Methods}

Weevil collection and maintenance

Adult M. undecimpustulatus undatus were collected from mature Australian pine, Casuarina equisetifolia L. (Casuarinaceae), in Fort Pierce, FL (27 $29^{\prime} 15.43^{\prime \prime}$ $\mathrm{N}, 80^{\circ} 24^{\prime} 33.79^{\prime \prime} \mathrm{W}$ ) about 1 week prior to each trial. The weevils were maintained in mesh-screened Bug Dorms $(60 \times 60 \times 60 \mathrm{~cm}$, BioQuip Products, Rancho Dominguez, CA) with the temperature at $24{ }^{\circ} \mathrm{C} \pm 2^{\circ}, 60 \% \mathrm{RH}$, and 14-h photoperiod. Three 40 -dram vials with snap-on lids with a $1-\mathrm{cm}$ hole cut into the lid were filled with water, and 2-3 branches of cocoplum, Chrysobalanus icaco L. (Chrysobalanaceae), of 25-30 cm length were inserted through the hole in the lid. Cocoplum was chosen for maintaining adults in the laboratory because the weevils readily eat it and the leaves were more easily accessible than Australian pine leaves and retained their food value longer in the laboratory. In each Bug Dorm, three plastic containers measuring $13 \mathrm{~cm}$ high $\times 12 \mathrm{~cm}$ wide (at top) and narrowing to $10 \mathrm{~cm}$ (at bottom) were lined with brown paper towel for an oviposition substrate, and one vial with cocoplum was placed into each container. Two small Petri dishes $(60 \times 15 \mathrm{~mm})$ were filled with a moistened, crumpled piece of brown paper towel to provide water to the weevils. Plants were changed weekly, and water was added to the dishes 2-3 times per week. Each Bug Dorm sustained up to 60 adult weevils.

\section{Cold tolerance}

Two experiments were conducted to test adult cold tolerance, with three trials each (June, July, and August) with a minimum temperature of $0{ }^{\circ} \mathrm{C}$ or $-5{ }^{\circ} \mathrm{C}$. In all trials, the plastic containers $\left(42 \times 29 \times 9 \mathrm{~cm}\right.$ Rubbermaid ${ }^{\circledR}$ Newell Brands, Atlanta, GA) used to contain adults were lined with brown paper towel. An $18 \times 13-\mathrm{cm}$ piece of the container's lid was replaced with fine mesh screen for ventilation. Two florist vials, each inserted with one $35-38 \mathrm{~cm}$ long branch of cocoplum with leaves, was placed in each container, along with a small Petri dish $(60 \times 15 \mathrm{~mm})$ filled with a crumpled piece of brown paper towel that was moistened to provide water to the weevils. All containers initially housed 25 fieldcollected adult weevils of unknown age and sex, held 
at $20{ }^{\circ} \mathrm{C}$ for $24 \mathrm{~h}$, and then used for exposure to cold temperatures in each experiment. Three control containers with 25 weevils each were held at $20^{\circ} \mathrm{C}$ throughout each experiment.

In one experiment, weevils under cold temperature treatments were gradually acclimated to lower temperatures starting at $20{ }^{\circ} \mathrm{C}$ and stepping down $5{ }^{\circ} \mathrm{C}$ every $24 \mathrm{~h}$ to a final test temperature of $0{ }^{\circ} \mathrm{C}$ in environmentally controlled chambers with $60 \% \mathrm{RH}$ and 14-h photoperiod. At the end of each exposure interval of $0.5,1,2,4$, and 8 days at $0{ }^{\circ} \mathrm{C}$, five weevils were removed from each container (15 weevils/exposure period/trial, 45 weevils per $0{ }^{\circ} \mathrm{C}$ exposure interval across three trials, 225 total weevils tested) and placed in a Petri dish $(35 \times 10 \mathrm{~mm})$ lined with Whatman ${ }^{\circledR}$ grade No.1 filter paper moistened with $200 \mu \mathrm{l}$ of distilled water. The Petri dishes were held at room temperature $\left(23-26{ }^{\circ} \mathrm{C}\right)$ for $24 \mathrm{~h}$, and then dead and live weevils were counted. A weevil was scored alive if leg or antennal movement was observed initially or after gentle prodding. The same procedure was used for the three trials of a second experiment except that adults were exposed to $0{ }^{\circ} \mathrm{C}$ for $24 \mathrm{~h}$ before exposure to $-5{ }^{\circ} \mathrm{C}$ for $0.5,1,2,4$, and 8 days. At the same time cold treatment weevils were sampled in both experiments, five control weevils were sampled from each of three containers at $20{ }^{\circ} \mathrm{C}$ and evaluated for survival in a manner similar to those under cold treatments.

Adult survival rates were compared among the different exposure intervals within each cold tolerance experiment, including survival without cold exposure. Using the Univariate procedure, the Shapiro-Wilk W test and normality plots validated the assumptions of parametric analysis (SAS Institute 2009). Data were subjected to ANOVA by using the GLM procedure to evaluate treatment effects on the weevil, and treatment means were separated using LSD contingent on a significant treatment effect $(\alpha=0.05)$. The effect of temperature and exposure time was also analyzed by a logistic model and the inverse prediction function (SAS Institute 2017). This analysis estimated the times required to kill $50 \%\left(\mathrm{LT}_{50}\right)$ and $90 \%\left(\mathrm{LT}_{90}\right)$ of the adult population at a specific temperature.

Sustained cold exposure versus repeated cold exposure

Adult weevils used in the experiments were collected from Australian pine on August 17, 2014 (summer) and January 17, 2015 (winter). Approximately one week prior to weevil collections, temperatures at the collection site ranged $20-34{ }^{\circ} \mathrm{C}$ in August and $6-26{ }^{\circ} \mathrm{C}$ in January (Florida Automated Weather Network 2017). Cocoplum branches with leaves of similar age and size $(25 \mathrm{~cm})$ were washed with water and allowed to air dry. Each treatment/exposure time utilized five replicated plastic containers $\left(27 \times 16 \times 8 \mathrm{~cm}\right.$, Great Value ${ }^{\circledR}$ Wal-Mart Stores, Inc., Bentonville, AR). Ten weevils from the same collecting event were added to each container along with one florist tube filled with water supporting one cocoplum branch (sample size/treatment $=50$ weevils).

All experiments were conducted in environmentally controlled chambers maintained at $60 \% \mathrm{RH}$ and a 14-h photoperiod (the latter remained constant to not introduce a possibly contributing variable factor to the experiment design and resultant data). Weevils in the sustained cold exposure treatments gradually acclimated from $20^{\circ}$ to $-5{ }^{\circ} \mathrm{C}$ as described for the cold tolerance experiments, at which time they were held at $-5{ }^{\circ} \mathrm{C}$ for $10 \mathrm{~h}$ and returned to $20^{\circ} \mathrm{C}$. Weevils in the repeated cold exposure treatments were initially gradually acclimated to $-5{ }^{\circ} \mathrm{C}$ and then held for one (I), two (II), three (III), or four (IV) 2-h exposure periods at $-5^{\circ} \mathrm{C}$, each exposure period separated by $22 \mathrm{~h}$ at $20^{\circ} \mathrm{C}$ (Table 1). Twenty-four h after the end of the final low temperature exposure period, adult survival was confirmed by leg or antennal movement. Control weevils were maintained at $20^{\circ} \mathrm{C}$ and evaluated for survival as those in the sustained cold exposure and repeated cold exposure experiments. Survivors remained in their original containers and received new food and water. Leaf consumption was determined 4 days later by quantifying the unconsumed area of each leaf lamina with ImageJ software (Rasband 2014). This Java-based application for analyzing images re-creates the original leaf shape by filling in areas lost to herbivory. The amount of herbivory was calculated as the difference between pre- and post-herbivory surface areas.

Data were analyzed for effects of cold treatment (sustained cold exposure and repeated cold exposure) and time of year (summer versus winter) on adult survival and herbivory. Normality of the data was checked in JMP Pro by using the Shapiro-Wilk Test. The $p$ values were greater than 0.2412 , thus not rejecting the null hypothesis that the data are normally 
Table 1 Experimental design of sustained cold exposure (SCE) and repeated cold exposure (RCE) experiments on adult Myllocerus undecimpustulatus undatus adults collected from the field in August 2014 and January 2015

\begin{tabular}{lllll}
\hline Treatment & $\begin{array}{l}\text { Temperature of exposure/recovery } \\
\left({ }^{\circ} \mathrm{C}\right)\end{array}$ & $\begin{array}{l}\text { Frequency of } \\
\text { exposure }\end{array}$ & $\begin{array}{l}\text { Duration of exposures/recovery } \\
\text { time }\end{array}$ & $\begin{array}{l}\text { No. of } \\
\text { exposures }\end{array}$ \\
\hline Control & $20 / 20$ & Continual & 8 days & N/A \\
SCE & $-5 / 20$ & Daily for 1 day & $10 \mathrm{~h} / 14 \mathrm{~h}+4$ days & 1 \\
RCE I & $-5 / 20$ & Daily for 1 day & $2 \mathrm{~h} / 22 \mathrm{~h}+4$ days & 1 \\
RCE II & $-5 / 20$ & Daily for 2 days & $2 \mathrm{~h} / 22 \mathrm{~h}+4$ days & 2 \\
RCE III & $-5 / 20$ & Daily for 3 days & $2 \mathrm{~h} / 22 \mathrm{~h}+4$ days & 3 \\
RCE IV & $-5 / 20$ & Daily for 4 days & $2 \mathrm{~h} / 22 \mathrm{~h}+4$ days & 4 \\
\hline
\end{tabular}

distributed. Therefore, survival and leaf area consumption means were compared with a one-way ANOVA, and means were separated with Tukey's HSD test $(\alpha=0.05)$ (SAS Institute 2009).

Niche modeling

Historical data of $M$. undecimpustulatus undatus collections in Florida were obtained from Michael Thomas of FDACS, DPI, Gainesville, FL. These data were collected from the start of the weevil's first known occurrence in September 2000 and proceeded through to January 2015. The geographic coordinates of each collection location were imported into DIVAGIS 7.5 (Hijmans et al. 2012). Bioclimatic variables (average for years 1970-2000) were downloaded from WorldClim 2.0 (Fick and Hijmans 2017) with a set of global climate layers at a spatial resolution of approximately $1 \mathrm{~km}^{2}$. Temperature and precipitation parameters were selected by using the BIOCLIM tool (Busby 1991) within this program. The geographic coordinates (data points) were used to identify the potential distribution in Florida based on mean annual temperature and precipitation. Utilizing the same data points, potential distribution was projected on a North American map by using the BIOCLIM tool and selecting isothermality and annual precipitation parameters. In combination with this statistical correlative model projections, a mechanistic model was developed with the biological data from the cold tolerance experiment. This model identified areas in North America where there are at least four consecutive days with average daily air temperatures at or below $0{ }^{\circ} \mathrm{C}\left(\mathrm{LT}_{90}\right.$ determined in the sustained cold tolerance experiment). Maps were imported to ArcGis
10.2, and an isothermal line was created that predicts the northern limit suitable for M. undecimpustulatus undatus establishment.

\section{Results}

Cold tolerance of adults

A significant negative effect $(P<0.0001)$ of low temperature on adult survival of $M$. undecimpustulatus undatus was observed for the $0{ }^{\circ} \mathrm{C}$ and $-5{ }^{\circ} \mathrm{C}$ treatments (Table 2). The trend of reduced survival with increasing exposure to low temperature was evident in both experiments. Weevil survival was always $100 \%$ in the control treatments at constant $20{ }^{\circ} \mathrm{C}$ and until the insects were exposed to the minimum temperatures in both experiments. After 2 days of exposure, survival was $40-73 \%$ (mean $=$ $60 \%)$ at $0{ }^{\circ} \mathrm{C}$ and $13-20 \%($ mean $=18 \%)$ at $-5{ }^{\circ} \mathrm{C}$. After 4 days of exposure, $7-13 \%($ mean $=11 \%)$ and $0-7 \%($ mean $=4 \%)$ of weevils survived at $0{ }^{\circ} \mathrm{C}$ and $-5{ }^{\circ} \mathrm{C}$, respectively. No weevils survived 8 days of exposure to the minimum temperatures (Table 2). All surviving weevils returned to ambulatory behavior within $48 \mathrm{~h}$.

A logistic fit analysis of weevil response to temperature by exposure time (days) for each of the three trials of each final temperature exposure experiment showed no significant differences among trials at $0{ }^{\circ} \mathrm{C}$ (Logistical Model $X^{2}>54.03, P<0.0001$; Overlapping Confidence Intervals of $50 \%=1.54-3.14$ ) nor $-5{ }^{\circ} \mathrm{C}$ (Logistical Model $X^{2}>46.5, \quad \mathrm{P}<0.0001 ;$ Overlapping Confidence Intervals of $50 \%=0.56-1.56$ ). Therefore, all data 
Table 2 Mean percentage survival of field-collected adult Myllocerus undecimpustulatus undatus following exposure to $0{ }^{\circ} \mathrm{C}$ or $-5{ }^{\circ} \mathrm{C}$ for $0.5,1,2,4$, or 8 days during experiments conducted in three consecutive months

\begin{tabular}{|c|c|c|c|c|c|c|c|c|}
\hline \multirow[t]{3}{*}{ Exposure time (day) } & \multicolumn{2}{|l|}{ June } & \multicolumn{2}{|l|}{ July } & \multicolumn{2}{|l|}{ August } & \multicolumn{2}{|c|}{ Overall mean } \\
\hline & \multicolumn{2}{|c|}{ Temperature } & \multicolumn{2}{|c|}{ Temperature } & \multicolumn{2}{|c|}{ Temperature } & \multicolumn{2}{|c|}{ Temperature } \\
\hline & $0^{\circ}$ & $-5^{\circ}$ & $0^{\circ}$ & $-5^{\circ}$ & $0^{\circ}$ & $-5^{\circ}$ & $0^{\circ}$ & $-5^{\circ}$ \\
\hline 0 & $100 \mathrm{a}$ & $100 \mathrm{a}$ & $100 \mathrm{a}$ & $100 \mathrm{a}$ & $100 \mathrm{a}$ & $100 \mathrm{a}$ & $100 \mathrm{a}$ & $100 \mathrm{a}$ \\
\hline 0.5 & $86.7 \mathrm{ab}$ & $60.0 \mathrm{~b}$ & $80.0 \mathrm{ab}$ & $66.7 \mathrm{~b}$ & $93.3 \mathrm{a}$ & $73.3 \mathrm{~b}$ & $82.2 \mathrm{~b}$ & $66.7 \mathrm{~b}$ \\
\hline 1 & $80.0 \mathrm{ab}$ & $33.3 \mathrm{c}$ & $73.3 \mathrm{~b}$ & $33.3 \mathrm{c}$ & $80.0 \mathrm{ab}$ & $26.7 \mathrm{c}$ & $82.2 \mathrm{~b}$ & $31.1 \mathrm{c}$ \\
\hline 2 & $73.3 \mathrm{~b}$ & $20.0 \mathrm{~d}$ & $66.7 \mathrm{~b}$ & $13.3 \mathrm{~d}$ & $40.0 \mathrm{bc}$ & $20.0 \mathrm{~cd}$ & $60.0 \mathrm{c}$ & $17.8 \mathrm{~d}$ \\
\hline 4 & $6.7 \mathrm{c}$ & $6.7 \mathrm{e}$ & $13.3 \mathrm{c}$ & $0.0 \mathrm{~d}$ & $13.3 \mathrm{c}$ & $6.7 \mathrm{de}$ & $11.1 \mathrm{~d}$ & $4.4 \mathrm{e}$ \\
\hline 8 & $0.0 \mathrm{c}$ & $0.0 \mathrm{e}$ & $0.0 \mathrm{c}$ & $0.0 \mathrm{~d}$ & $0.0 \mathrm{c}$ & $0.0 \mathrm{e}$ & $0.0 \mathrm{~d}$ & $0.0 \mathrm{e}$ \\
\hline
\end{tabular}

Means with the same letters within each column are not significantly different (ANOVA, LSD, $\alpha=0.05$ )

among trials in each final temperature exposure experiment were combined for calculating the $\mathrm{LT}_{50}$ and $\mathrm{LT}_{90}$. At $0{ }^{\circ} \mathrm{C}$, the $\mathrm{LT}_{50}$ was 2.3 days, and the $\mathrm{LT}_{90}$ was 4.0 days (Fig. $2 \mathrm{a}$ ). At $-5{ }^{\circ} \mathrm{C}$, the $\mathrm{LT}_{50}$ was 1 day, and the $\mathrm{LT}_{90}$ was 2.3 days (Fig. 2b).

Sustained cold exposure versus repeated cold exposure

Survival of weevils collected in summer was significantly reduced in the sustained cold exposure treatment compared to survival in the control and repeated cold exposure treatments $(F=7.1, \mathrm{df}=5,25$, $P<0.001)$. Mortality was at least 3.4-times higher in the sustained cold exposure treatment compared to all other treatments (Fig. 3). There was no significant effect of sustained cold exposure treatment or repeated cold exposure treatments on survival of weevils collected in winter $(F=2.6$, df $=5,29 ; P>0.05)$ (Fig. 3). All surviving weevils returned to ambulatory behavior within $48 \mathrm{~h}$.

Leaf consumption by summer weevils was not significantly different among the constant $20{ }^{\circ} \mathrm{C}$ control treatment and repeated cold exposure treatments, whereas weevils in the sustained cold exposure treatments consumed significantly less than weevils in repeated cold exposure treatments III and IV $(F=7.2$; $\mathrm{df}=5,29 ; P<0.0001)$ (Fig. 4). Leaf consumption by winter weevils decreased as the number of repeated cold exposure periods increased and was least in the sustained cold exposure treatment. Average leaf area consumed by winter weevils was greater than that consumed by summer weevils, being 4.0-times greater

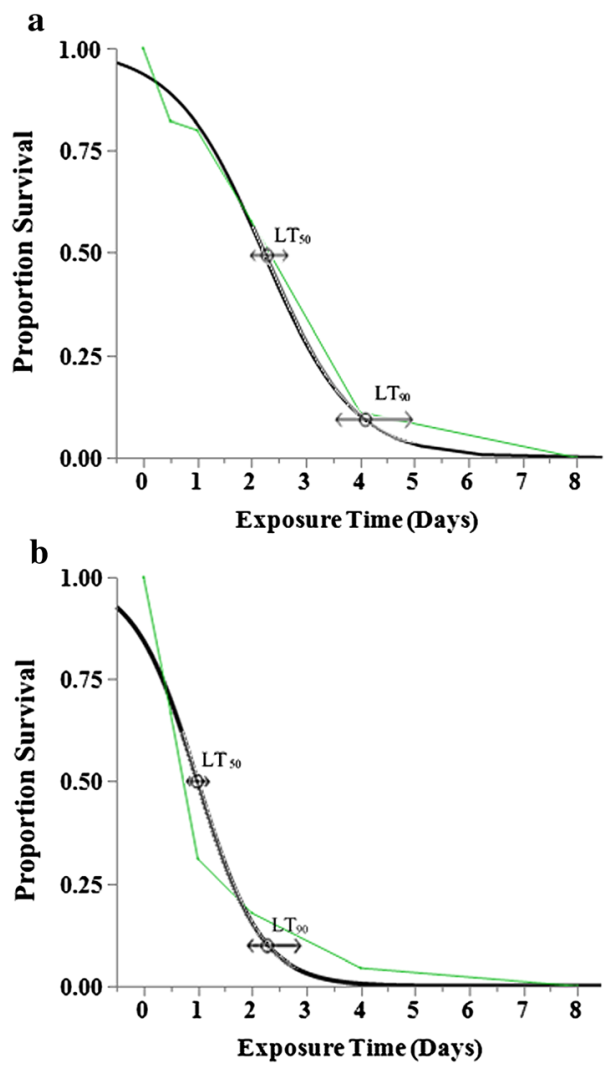

Fig. 2 Survival response models for adult Myllocerus undecimpustulatus undatus exposed to $\mathbf{a} 0{ }^{\circ} \mathrm{C}$ and $\mathbf{b}-5^{\circ} \mathrm{C}$. The green line represents observed data. $\mathrm{LT}_{50}$ and $\mathrm{LT}_{90}$ are the estimated number of days to kill $50 \%$ and $90 \%$, respectively, of the population; arrows extending each side of the LT points indicate the standard error of the mean 


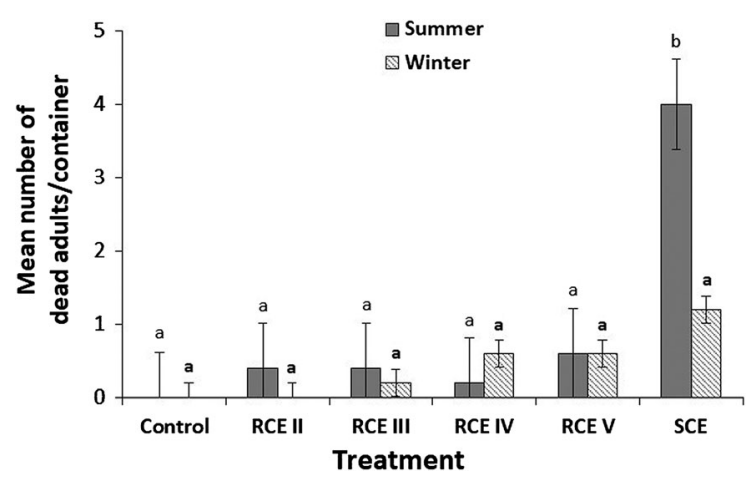

Fig. 3 Mean $( \pm \mathrm{SE})$ number of dead summer- and wintercollected adult Myllocerus undecimpustulatus undatus after repeated cold exposure (RCE) and sustained cold exposures (SCE) to $-5{ }^{\circ} \mathrm{C}$. Weevils in the RCE treatments were held for one (I), two (II), three (III), or four (IV) 2-h exposures. Columns for summer-collected weevils and columns for winter-collected weevils with different letters are significantly different (Tukey's HSD test, $P<0.05$ )

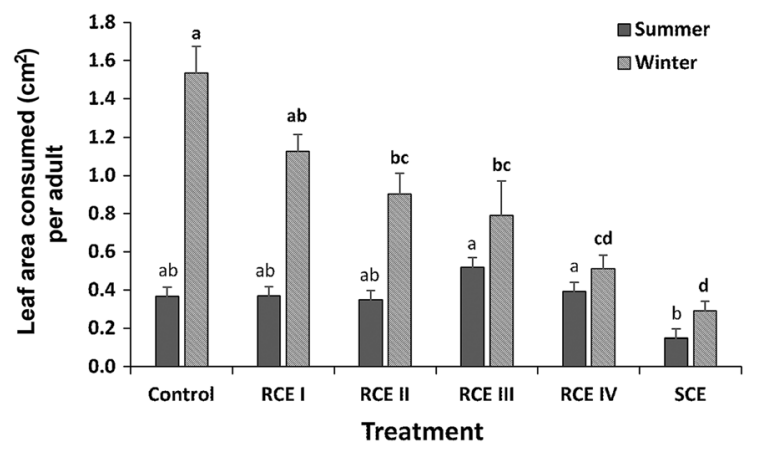

Fig. 4 Mean ( \pm SE) leaf area consumed by summer- and winter-collected adult Myllocerus undecimpustulatus undatus after repeated cold exposure (RCE) and sustained cold exposures (SCE) to $-5{ }^{\circ} \mathrm{C}$. Weevils in the RCE treatments were held for one (I), two (II), three (III), or four (IV) 2-h exposures. Columns for summer-collected weevils and columns for winter-collected weevils with different letters are significantly different (Tukey's HSD test, $P<0.05$ )

than by weevils in the constant $20{ }^{\circ} \mathrm{C}$ control treatment $\left(1.53 \mathrm{~cm}^{2}\right.$ per weevil vs. $0.37 \mathrm{~cm}^{2}$ per weevil, respectively) and 2.0 times greater than by weevils in the sustained cold exposure treatment $(0.30$ $\mathrm{cm}^{2}$ per weevil vs. $0.15 \mathrm{~cm}^{2}$ per weevil, respectively).

Niche modeling

An isothermal line based on cold exposure survival data at $0{ }^{\circ} \mathrm{C}$ predicts that climatic conditions are suitable for M. undecimpustulatus undatus in all of
Florida and Louisiana, the southern portions of South Carolina, Georgia, Alabama, Mississippi, Arkansas, Texas, New Mexico, Arizona, and Nevada, a majority of California, and western Oregon (Fig. 5). A niche model based on voucher collections data predicted the ability of $M$. undecimpustulatus undatus to survive in South Carolina, Georgia, Alabama, Louisiana, and portions of southern North Carolina, Mississippi, southeastern Texas, northern California, western Oregon and Washington, eastern Mexico, and the Bahamas (Fig. 5). The highest probability areas (Fig. 5, red and orange) are in Florida, southern Georgia, northern California, western Oregon, along with eastern Mexico and the Bahamas. An area from the Florida panhandle westward along the Gulf Coast was defined as not suitable for this weevil in the niche model.

\section{Discussion}

Some weevils exposed to $-5^{\circ} \mathrm{C}$ for 4 days survived, suggesting that $M$. undecimpustulatus undatus can tolerate cold temperatures not experienced in their native range. Insects that demonstrate adaptations to cooler temperatures have evolved various physiological mechanisms to survive (Renault et al. 2004). However, adult M. undecimpustulatus undatus may have suffered sublethal damage or tradeoffs, such as have been observed in the development, reproduction, and tissues and cells of other insects (Marshall and Sinclair 2010). For example, Rueda and Axtell (1996) found that reproduction and development in an adult tropical darkling beetle, Alphitobius diaperinus Panzer (Coleoptera: Tenebrionidae), was inhibited at temperatures below $17{ }^{\circ} \mathrm{C}$. There could also be a possibility of tradeoffs based on the immediate thermal history of the beetles, thus compromising their tolerance to the other extremes such as wintercollected weevils for tolerance of high summer temperatures and vice versa.

The differential effect of temperature fluctuations on adult $M$. undecimpustulatus undatus collected in summer and winter was particularly manifested in herbivory, which was notably greater in wintercollected weevils exposed to repeated cold exposure and sustained cold exposure treatments; differences in mortality between winter and summer weevils treated to repeated cold exposure were not clear, but more 


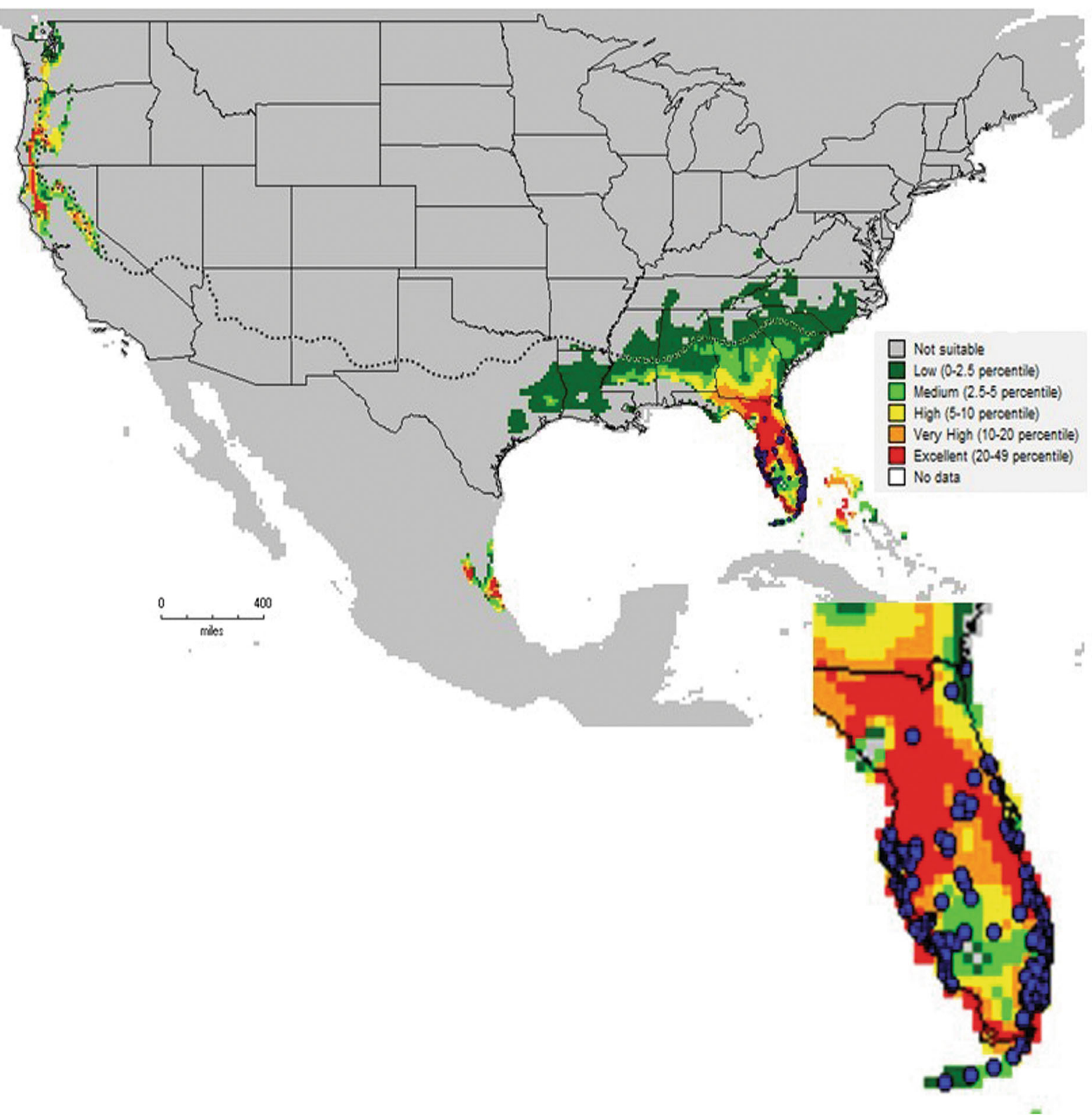

Fig. 5 Isothermal line (dashed) predicting the northern distribution limits of Myllocerus undecimpustulatus undatus based on daily air temperatures of $0{ }^{\circ} \mathrm{C}$ for at least 4 days $\left(\mathrm{LT}_{90}\right)$. Colored areas indicate where $M$. undecimpustulatus undatus is predicted to occur by DIVA-GIS BIOCLIM utilizing two

winter weevils than summer weevils survived the sustained cold temperature treatment. Renault et al. (2004) surmised returning to higher temperatures may provide for the repair of injuries sustained when $A$. diaperinus experienced $5^{\circ}$ and $0{ }^{\circ} \mathrm{C}$ for $22 \mathrm{~h}$ /day and then returned to $20{ }^{\circ} \mathrm{C}$ for $2 \mathrm{~h}$. They also found that the climate variables, isothermality and annual precipitation. Color is indicative of the probability of occurrence from low (dark green) to high (red). Inset: Peninsular Florida with blue dots representing weevil collection locations

beetles exposed to repeated cold exposure had greatly improved survival over beetles kept continuously at lower temperatures. Marshall and Sinclair (2012) concluded that $D$. melanogaster's response to repeated cold exposure versus sustained cold exposure always resulted in higher survival, which could be attributed 
to the cumulative effect of the physiological impact of repeated cold and warm cycles. Anderson et al. (2017) found improved chill coma recovery, cellular survival, and cold tolerance in the migratory locust, Locusta migratoria Linnaeus (Orthoptera: Acrididae), after brief periods of cold exposure.

Seasonality appears to be a factor in cold tolerance by adult $M$. undecimpustulatus undatus. Winter weevil survival was twice that of summer weevils in the sustained cold exposure treatments. Similarly, Russell et al. (2017) found the survival of South American salvinia weevils, Cyrtobagous salviniae Calder and Sands, was greater and chill coma recovery was faster in weevils that had experienced longer durations of cold temperatures before being exposed to $0{ }^{\circ} \mathrm{C}$ treatments. Russell (2017) found similar results with summer- and winter- treated salvinia weevils from Louisiana; specifically, survival increased 1.8 times and chill coma recovery was 1.5 times faster in the winter-collected weevils compared to those collected in the summer.

Leaf consumption after cold exposure was higher for M. undecimpustulatus undatus weevils collected in winter. Winter weevils experienced natural cooling events preceding collection when temperatures dipped to about $4{ }^{\circ} \mathrm{C}$ for weeks, leading to several natural repeated cold exposures. This may have increased the weevil's adaptive ability to withstand the cold exposures experienced during the experiment. This suggests that $M$. undecimpustulatus undatus has the potential to expand its distribution northward of subtropical southern Florida and survive the modulating winter temperatures in the southern and western regions of temperate North America.

Identifying climatic factors correlated to the native distribution of $M$. undecimpustulatus undatus is important in projecting its spread within North America. Being a polyphagous insect free of specific natural enemies, temperature, precipitation, and soil moisture are likely the most impactful environmental components that determine the constraint of where $M$. undecimpustulatus undatus may live. The lowlands of Sri Lanka have an annual mean temperature of $27.5{ }^{\circ} \mathrm{C}$ and annual rainfall of 900-2000 mm (Department of Meteorology Sri Lanka 2021) compared to $21.5{ }^{\circ} \mathrm{C}$ and $1016-1524 \mathrm{~mm}$ in peninsular Florida (Linacre and Geerts 1998). The niche model showed an area from the western Florida Panhandle westward along the Gulf Coast (grey area in Fig. 5) as not suitable for $M$. undecimpustulatus undatus. This area receives about $1524-1778 \mathrm{~mm}$ of annual rainfall (Linacre and Geerts 1998), similar to the upper rainfall range in Sri Lankan lowlands but more than that received in peninsular Florida. Moreover, this area of the Gulf Coast is predominantly wetlands with aquic or udic soil (U. S. Department of Agriculture 2017) compared to the well-drained sandy soil of the Florida Peninsula. These rainfall and soil differences lead to the suggestion that the western Gulf Coast region is too wet for larvae of M. undecimpustulatus undatus to survive.

The spatial coincidence of the isothermal line based on cold exposure experiments and the climate niche model increases assurance in the prediction of where M. undecimpustulatus undatus has the possibility of surviving. The niche model and the isothermal line provide projections that $M$. undecimpustulatus undatus could spread north and west within the United States. There is no published information on the flight behavior of this weevil, but we have seen short flights in the laboratory and field. Therefore, flight may not be a significant long-distance dispersal mechanism. The most likely method of movement to new geographic areas is through accidental transport by commerce, specifically potted plant materials grown in Florida and distributed to other areas below the isothermal line in Fig. 5. Adult weevils tend to hide on the undersides of leaves out of direct view and drop to the soil if disturbed. Weevil eggs and larvae in the potting media may be simply carried to other destinations. Shippers of potted plant materials should first inspect foliage for chewing damage from adults and treat infested plant material and soil appropriately before distribution per Florida Statute 581.161. California has intercepted this weevil six times between 2000 and 2017, typically on nursery stock from Florida (Iqbal 2017). The California Department of Food and Agriculture currently has a proposal to rank M. undecimpustulatus undatus as an "A", which means there is the expectation of significant economic and environmental impacts if it were to establish within the state (Iqbal 2017).

Climate change predicts several temperature and precipitation changes that include milder winters, colder cold fronts, more frequent hurricanes, and more extensive flooding (Meehl et al. 2007; Ornes 2018). The extreme events affect the distribution and population dynamics of insects. Our study measured 
survival of a subtropical insect exposed to $0{ }^{\circ} \mathrm{C}$ and $-5{ }^{\circ} \mathrm{C}$ and predicted its northern invasive edge under current climate conditions. Cold fronts influenced by climate changes might produce temperatures below $-5{ }^{\circ} \mathrm{C}$ in our northern prediction range, resulting in increased mortality and moving our predicted northern edge southward. Conversely, milder winters might result in the establishment of population of $M$. undecimpustulatus undatus in areas where they previously could not survive, thus moving the predicted edge northward (Rehm et al. 2015). Predicted increases of precipitation and flooding could adversely influence pupal mortality due to saturated soils. Further studies are recommended to estimate the possible consequences of climate change on the projected northern invasion of $M$. undecimpustulatus undatus.

In conclusion, our study indicated phenotypic plasticity in the cold tolerance of $M$. undecimpustulatus undatus acclimated to winter conditions. In addition, it provides a greater comprehension of the temperature requirements that influence the population dynamics and dispersal of $M$. undecimpustulatus undatus in a global landscape. This information is a critical component in developing an effective management plan for this weevil's current and potential distribution. A comprehensive determination of the effect of cold temperature should include the influence of low temperature on fecundity and longevity of the insect. The immature stages of $M$. undecimpustulatus undatus live in the soil, which may provide a buffer to cooler air temperatures. But low soil temperature effects on larval and pupal survivorship should also be studied.

Acknowledgements We are grateful to Michael Thomas (deceased), Florida Department of Agriculture and Consumer Services, Division of Plant Industry and field inspectors for sharing their data collection locations and plant host information for the weevils. Special thanks are extended to Norman Platts, homeowner, Fort Pierce, FL for allowing collection of weevils, and Janet Dawson (University of Florida) for assistance with weevil colony maintenance. We acknowledge the Florida Department of Agriculture and Consumer Services for being the major sponsor of this research. We also extend our thanks to two anonymous reviewers whose feedback significantly improved the manuscript.

Authors' contributions Both ASN and RDC conceived the project. ASN and RD built and analyzed the models. ASN and JAQ statistically analyzed the cold tolerance data. ASN led the preparation of the manuscript, and both ASN and RDC contributed to the final version. All authors reviewed and approved the manuscript.

Funding This research was funded in part by the from Florida Department of Agriculture and Consumer Services.

Availability of data and material The datasets generated during and/or analyzed during the current study are available from the corresponding author on reasonable request.

Code availability Not applicable.

\section{Declarations}

Conflicts of interest The authors have no conflicts of interest.

Ethics approval Not applicable.

Consent to participate Not applicable.

Consent for publication Not applicable.

Open Access This article is licensed under a Creative Commons Attribution 4.0 International License, which permits use, sharing, adaptation, distribution and reproduction in any medium or format, as long as you give appropriate credit to the original author(s) and the source, provide a link to the Creative Commons licence, and indicate if changes were made. The images or other third party material in this article are included in the article's Creative Commons licence, unless indicated otherwise in a credit line to the material. If material is not included in the article's Creative Commons licence and your intended use is not permitted by statutory regulation or exceeds the permitted use, you will need to obtain permission directly from the copyright holder. To view a copy of this licence, visit http://creativecommons.org/licenses/by/4.0/.

\section{References}

Amarasekare KG, Chong J-H, Epsky N, Mannion C (2008) Effect of temperature on the life history of the mealybug Paracoccus marginatus (Hemipteran: Pseudococcidae). J Econ Entomol 101:1798-1804

Anderson M, Folkersen R, MacMillian H, Overgaard J (2017) Cold acclimation improves chill tolerance in the migratory locust through preservation of ion balance and membrane potential. J Exp Biol 220:487-496

Andrewartha HG, Birch LC (1954) The distribution and abundance of animals. University of Chicago Press, Chicago

Araújo MB, Peterson AT (2012) Uses and misuses of bioclimatic envelope modeling. Ecol 93:1527-1539

Arévalo HA, Stansly PA (2009) Suppression of Myllocerus undatus (Coleoptera: Curculionidae) in Valencia orange with chlorpyrifos spray directed at ground and foliage. Fla Entomol 92:150-152

Atwal AS (1976) Agricultural pests of India and South-East Asia. Kalyani Publishers, New Delhi 
Bale JS (2002) Insects and low temperatures; from molecular biology to distributions and abundance. Philos Trans R Soc B 357:849-862

Busby JR (1991) BIOCLIM: a bioclimate analysis and prediction system. In: Margules CR, Austin MP (eds) Nature conservation: cost effective biological surveys and data analysis. CSIRO, Canberra, pp 64-68

Chong J-H, Roda AL, Mannion CM (2008) Mortality of the lobate lac scale Paratachardina pseudolobata (Hemiptera: Kerriidae) at near or below freezing temperatures. Fla Entomol 91:674-678

Current Results Publishing Ltd (2021) Current results weather and science facts, Florida weather averages. https://www. currentresults.com/Weather/Florida/average-floridaweather.php. Accessed 30 Apr 2021

Department of Meteorology Sri Lanka (2021) Climate of Sri Lanka. http://www.meteo.gov.lk/index.php?option=com content $\&$ view $=$ article $\&$ id=94\&Itemid=310\&lang=en . Accessed 30 Apr 2021

Diaz R, Overholt WA, Samayoa A, Sosa F, Cordeau D, Medal J (2008) Temperature-dependent development, cold tolerance, and potential distribution of Gratiana boliviana (Coleoptera: Chrysomelidae), a biological control agent of tropical soda apple, Solanum viarum (Solanaceae). Biocontrol Sci Technol 18:193-207

Elith J, Leathwick JR (2009) Species distribution models: ecological explanation and prediction across space and time. Ann Rev Evol Syst 40:677-697

Epsky ND, Walker A, Kendra PE (2009) Sampling methods for Myllocerus undecimpustulatus undatus (Coleoptera: Curculionidae) adults. Fla Entomol 92:388-390

Fick SE, Hijmans RJ (2017) Worldclim 2: new 1-km spatial resolution climate surfaces for global land areas. Int $\mathrm{J}$ Climatol 37:4302-4315

Florida Automated Weather Network (2017) https://fawn.ifas. ufl.edu/data/reports. Accessed 20 June 2018

Franklin J (2010) Mapping species distributions: spatial inference and prediction. Cambridge University Press, Cambridge

Guisan A, Zimmermann NE (2000) Predictive habitat distribution models in ecology. Ecol Model 135:147-186

Hijmans RJ, Guarino L, Mathur P (2012) DIVA-GIS. Vsn. 7.5. A geographic information system for the analysis of species distribution data. http://www.diva-gis.org/docs/ DIVA-GIS_manual_7.pdf. Accessed 30 Apr 2021

Iqbal J (2017) Sri Lankan weevil I Myllocerus undecimpustulatus undatus. [Blog post]. http://blogs.cdfa.ca.gov/ Section3162/?p=3824. Accessed 30 Apr 2017

Jarnevich CS, Stohlgren TJ, Kumar S, Morisette JT, Holcombe TR (2015) Caveats for correlative species distribution modeling. Ecol Inform 29:6-15

Kearney MR, Wintle BA, Porter WP (2010) Correlative and mechanistic models of species distribution provide congruent forecasts under climate change. Conserv Lett 3:203-213

Lalouette L, Williams CM, Hervant F, Sinclair BJ, Renault D (2007) Metabolic rate and oxidative stress in insects exposed to low temperature thermal fluctuations. Comp Biochem Physiol A Mol Integr Physiol 158:229-234

Lapointe SL, Borchert DM, Hall DG (2007) Effect of low temperatures on mortality and oviposition in conjunction with climate mapping to predict spread of the root weevil Diaprepes abbreviatus and introduced natural enemies. Environ Entomol 36:73-82

Linacre E, Geerts B (1998) Rainfall and rainfall changes in the USA. http://www-das.uwyo.edu/ geerts/cwx/notes/ chap17/rain_usa.html. Accessed 30 Apr 2021

Mannion C, Hunsberger A, Gabel K, Buss E, Buss L (2006) Sri Lanka weevil (Myllocerus undatus). University of Florida/ IFAS, Tropical Research and Education Center. http:// entomology.ifas.ufl.edu/creatures/orn/sri_lankan_weevil. htm. Accessed 7 Apr 2018

Manrique V, Cuda JP, Overholt WA, Diaz R (2008) Temperature-dependent development and potential distribution of Episimus utilis (Lepidoptera: Tortricidae), a candidate biological control agent of Brazilian peppertree (Sapindales: Anacardiaceae) in Florida. Environ Entomol 37:862-870

Manrique V, Diaz R, Montemayor C, Serrano D, Cave RD (2012) Temperature-dependent development and cold tolerance of Microtheca ochroloma (Coleoptera: Chysomelidae), a pest of cruciferous crops in the southeastern United States. Ann Entomol Soc Am 105:859-864

Marshall KE, Sinclair BJ (2010) Repeated stress exposure results in survival-reproduction trade-off in Drosophilia melanogaster. Proc Biol Sci 277:963-969

Marshall KE, Sinclair BJ (2012) The impacts of repeated cold exposure on insects. J Exp Biol 215:1607-1613

Meehl G, Stocker T, Collins W, Friedlingstein P, Gaye A, Solomon S, Qin D, Manning M, Chen Z, Marquis M (2007) Climate change, 2007: the physical science basis. In: Contribution of working group I to the fourth assessment report of the intergovernmental panel on climate change. Cambridge University Press, Cambridge, UK

Neal A (2013) Sri Lankan weevil, Myllocerus undecimpustulatus undatus Marshall (Coleoptera: Curculionidae, Entiminae). EENY-579. University of Florida/IFAS extension. http://entnemdept.ufl.edu/creatures/orn/sri_ lanan_weevil.htm. Accessed 5 May 2015.

O'Brien CW, Haseeb M, Thomas MC (2006) Myllocerus undecimpustulatus undatus Marshall (Coleoptera: Curculionidae), a recent discovered pest weevil from the Indian subcontinent. Entomology Circular No. 412. Fla Dept Agric Cons Serv, Gainesville.

Ornes S (2018) Core concept: how does climate change influence extreme weather? Impact attribution research seeks answers. PNAS 115:8232-8235

Ramamurthy VV, Ghai S (1988) A study on the genus Myllocerus (Coleoptera: Curculionidae). Orient Ins 22:377-500

Rasband WS (2014) ImageJ. U. S. National Institutes of Health. http://imagej.nih.gov/ij/, 1997-2014. Accessed 8 Sept 2015

Rehm EM, Olivas P, Stroud J, Freeley KJ (2015) Losing your edge: climate change and the conservation value of rangeedge populations. Ecol Evol 45:4315-4326

Renault D, Nedved O, Hervant F, Vernon P (2004) The importance of fluctuating thermal regimes for repairing chill injuries in the tropical beetle Alphitobius diaperinus (Coleoptera: Tenebrionidae) during exposure to low temperature. Physiol Entomol 29:139-145 
Rueda LM, Axtell RC (1996) Temperature-dependent development and survival of the lesser mealworm, Alphitobius diaperinus. Med Vet Entomol 10:80-86

Russell AD (2017) Cold tolerance and overwintering physiology of the salvinia weevil (Cytobagous salviniae): improving the biological control of giant salvinia in temperate Louisiana. Thesis, Louisiana State University

Russell A, Johnson S, Cibils X, McKay F, Moshman L, Madeira P, Blair Z, Diaz R (2017) Surveys in Argentina and Uruguay reveal Cyrtobagous salviniae (Coleoptera: Curculionidae) populations adapted to survive temperate climates in southeastern USA. Biol Control 107:41-49

Institute SAS (2009) Version 9.2. SAS Institute, Cary

SAS Institute Inc. (2017) JMP® 13.1 modeling and multivariate methods. SAS Institute Inc., Cary

Scheffrahn RH, Su N-Y (1999) West Indian drywood termite, Cryptotermes brevis (Walker) (Insecta: Isoptera: Kalotermitidae). University of Florida/IFAS, Ft. Lauderdale Research and Education Center. http://entnemdept.ufl.edu/ creatures/URBAN/TERMITES/Cryptotermes_brevis_west_ indian_drywood_termite.htm. Accessed 30 Apr 2021

Singh T, Bhat MM, Khan MA (2009) Insect adaptions to changing environments: temperature and humidity. Int J Indust Entomol 19:155-164
Stratman KN, Overholt WA, Cuda JP, Mukherjee A, Diaz R, Netherland MD, Wilson PC (2014) Temperature-dependent development, cold tolerance, and potential distribution of Cricotopus lebetis (Diptera: Chironomidae), a tip miner of Hydrilla verticillata (Hydrocharitaceae). J Insect Sci 14(1): 153

Tognelli MF, Roig-Juneñt SA, Marvaldi AE, Flores GE, Lobo JM (2009) An evaluation of methods for modelling distribution of Patagonian insects. Rev Chil Hist Nat $82: 347-360$

U. S. Department of Agriculture (2017) MLRA 152A Eastern Gulf Coast Flatwoods. USDA Natural Resources Conservation Service soil survey site. http://www.nrcs.usda.gov/ $\mathrm{wps} / \mathrm{portal} / \mathrm{nrcs} / \mathrm{detail} / \mathrm{soils} /$ survey/office/ssr7/tr/?cid=nrcs 142p2_048073. Accessed 17 July 2017

Walter H, Harnickell E, Mueller-Dombois D (1975) Climatediagram maps of the individual continents and the ecological climatic regions of the earth. Springer, Berlin

Publisher's Note Springer Nature remains neutral with regard to jurisdictional claims in published maps and institutional affiliations. 